\title{
AKUNTABILITAS PENGELOLAAN ALOKASI DANA DESA DALAM UPAYA MENINGKATKAN PEMBANGUNAN DAN PEMBERDAYAAN MASYARAKAT
}

\author{
Lina Nasihatun Nafidah \\ Mawar Suryaningtyas \\ STIE PGRI Dewantara Jombang
}

\begin{abstract}
This research focuses attention on accountability in the management of Village Funds Allocation (ADD) in efforts to improve the development of the village and community empowerment. This research is expected to be useful in efforts to improve the accountability of the management of Village Funds Allocation. The results of this research showed that the accountability ADD both technically and administration has een running well in accordance with the applicable rules with evidence of accountability in a transparent and accountable, so also in the management of village funds allocation, proven by the existence of Accountability Report (LPJ) the contents of which there is a cash book receipt, aiding, news events and other activities that have been documented through the pictures that are attached and physical development has been carried out the construction by constructing the irrigation water stones times. The realization of the report and report the realization of the implementation of Regional Budget Villages communicated to the society in writing and with themediainformation that is easily accessible by the community as shown by the existence of an attachment realization of that has been written. The planning, implementation, accountability for the development and empowerment of the village Dapurkejambon also has been done by the government of the village in accordance with the existing regulations, proven by the existence of the stages of planning activities can be done preparation in the form of the arrangement of the list of the Proposed Planned Activities (DURK) and Business Plan and Budget (RKA) that activities financed by the Fund Allocation of the village. However the purpose of the Fund Allocation Village in increasing community empowerment Dapurkejambon still deemed less than optimal because of the community less respond with good.
\end{abstract}

Key Words : Accountability, Village Funds Allocation, Development \& Empowerment of the Village 


\section{A. Pendahuluan}

Pemerintah Indonesia terus mengupayakan peningkatan pelaksanaan Pembangunan Nasional agar laju pembangunan daerah serta laju pembangunan desa dan kota semakin seimbang dan serasi. Namun pembangunan Nasional pada pelaksanaannya masih dihadapkan dengan masalah pokok pembangunan seperti ketimpangan pembangunan antara desa dan kota di Indonesia. Ketimpangan Pembangunan terjadi karena banyak faktor yang mempengaruhinya sehingga pembangunan di Indonesia tidak merata sehingga berdampak pada tingginya kemiskinan di Indonesia. Terkait dengan masalah kemiskinan, menurut data BPS jumlah penduduk miskin pada tahun 2012 penduduk kota dengan kemiskinan sebesar 8.60\% sedangkan kemiskinan di pedesaan sebesar $14.70 \%$. Menanggapi permasalahan tersebut, strategi pemerintah untuk mengatasi ketimpangan pembangunan yaitu dengan melaksanakan pembangunan nasional yang menaruh perhatian besar terhadap pembangunan desa.

Dalam pelaksanaan pemerintahan desa tersebut dituntut adanya suatu aspek tata pemerintahan yang baik (Good Governance), dimana salah satu karakteristik atau unsur utama dari Good Governance adalah akuntabilitas. Akuntabilitas dapat diartikan sebagai bentuk tanggungjawab pelaksanaan misi organisasi dalam mencapai tujuan yang telah ditetapkan melalui media pertanggungjawaban yang dilaksanakan secara periodik. Jadi, akuntabilitas pemerintahan sangat diperlukan sebagai penunjang penerapan otonomi desa agar dapat berjalan dengan baik (Aprisiami Putriyanti : 2012).

Desa adalah entitas terdepan dalam segala proses pembangunan bangsa dan negara. Hal ini menyebabkan desa memiliki arti sangat strategis sebagai basis penyelenggaraan pelayanan publik dan memfasilitasi pemenuhan hak-hak publik rakyat lokal. Sejak masa penjajahan Hindia Belanda sekalipun, pemerintah kolonial telah menyadari peran strategis desa dalam konstelasi ketatanegaraan pada masa itu. Di samping itu, Desa menjadi arena politik paling dekat bagi relasi antara masyarakat dengan pemegang kekuasaan (perangkat Desa).

Alokasi Dana Desa adalah dana yang diberikan kepada desa yang berasal dari dana perimbangan keuangan 
pemerintah pusat dan daerah yang diterima oleh Kabupaten/ Kota. Pemberian Alokasi Dana Desa merupakan wujud dari pemenuhan hak desa untuk menyelenggarakan otonominya agar tumbuh dan berkembang mengikuti pertumbuhan dari desa itu sendiri berdasarkan keanekaragaman, partisipasi, otonomi asli, demokratisasi, pemberdayaan masyarakat dan meningkatkan peran Pemerintah Desa dalam memberikan pelayanan dan meningkatkan kesejahteraan masyarakat serta memacu percepatan pembangunan dan pertumbuhan wilayahwilayah strategis. Alokasi Dana Desa sangat penting guna pembiayaan pengembangan -wilayah tertinggal dalam suatu sistem wilayah pengembangan. Pelaksanaan Alokasi Dana Desa ini ditujukan untuk program-program fisik dan non fisik yang berhubungan dengan indikator Perkembangan Desa, meliputi tingkat pendidikan, tingkat pendapatan masyarakat, dan tingkat kesehatan.

Hakekat pembangunan desa bertujuan untuk memperbaiki kondisi dan taraf hidup masyarakat. Di samping itu pemerintah desa merupakan suatu strategi pembangunan yang memungkinkan pemerataan pembangunan dan hasilhasilnya dinikmati oleh rakyatnya dan pertumbuhan ekonomi yang cukup tinggi dan tercapainya stabilitas keamanan wilayah yang sehat dan dinamis. Pemerintah desa sebagai alat untuk mencapai tujuan administrasi negara, berfungsi sebagai tangan panjang pemerintah dalam rangka pembangunan nasional demi tercapainya kesejahteraan rakyat yang merata. (Widjaja:2002).

Pemberdayaan merujuk pada serangkaian tindakan yang dilakukan secara sistematis dan mencerminkan pertahapan kegiatan atau upaya mengubah masyarakat yang kurang atau belum berdaya, berkekuatan, dan berkemampuan menuju keberdayaan. Makna "memperoleh" daya, kekuatan atau kemampuan merujuk pada sumber inisiatif dalam rangka mendapatkan atau meningkatkan daya, kekuatan, atau kemampuan sehingga memiliki keberdayaan. Kata "memperoleh" mengindikasikan bahwa yang menjadi sumber inisiatif untuk berdaya berasal dari masyarakat itu sendiri. Oleh karena itu, masyarakat harus menyadari akan perlunya memperoleh daya tau kemampuan. Makna kata "pemberian" menunjukkan bahwa sumber inisiatif bukan dari masyarakat. 
Inisiatif untuk mengalihkan daya, kemampuan atau kekuatan adalah pihak-pihak lain yang memiliki kekuatan dan kemampuan.

Kajian penelitian yang relevan dengan peneliatian ini yaitu terdapat dalam Penelitian yang dilakukan oleh Amin Rahmanurrasjid tahun 2008 yang berjudul "Akuntabilitas dan Transparansi dalam Pertanggungjawaban Pemerintah Daerah untuk Mewujudkan Pemerintahan yang Baik di Daerah (Studi di Kabupaten Kebumen)". Dalam penelitian tersebut disebutkan bahwa kebijakan desentralisasi dan implementasi otonomi daerah pada yang ada di Indonesia pada dasarnya menyangkut pengalihan kewenangan dan sumber daya dari pusat ke daerahdaerah. Dalam sistem pembagian kekuasaan berlaku prinsip bahwa setiap kekuasaan harus dipertanggungjawabkan. Karena itu, setiap kekuasaan harus dipikirkan beban tanggungjawab bagi setiap penerima kekuasaan. Untuk terwujudnya pelaksanaan otonomi daerah sejalan dengan upaya menciptakan pemerintahan yang bersih, bertanggungjawab serta mampu menjawab tuntutan perubahan secara efektif dan efisien sesuai dengan prinsip tata pemerintahan yang baik, maka Kepala Daerah wajib melaporkan penyelenggaraan pemerintahan daerah. Laporan dimaksud dalam bentuk LPPD, LKPJ, dan Informasi LPPD.Bagi Pemerintah LPPD dapat dijadikan salah satu bahan evaluasi untuk keperluan pembinaan terhadap pemerintah daerah.

Desa Dapurkejambon salah satu desa yang ada di Kabupaten Jombang dan sebagai salah satu objek penelitian adalah desa yang setiap tahunnya mendapatkan ADD. Dana yang diperoleh untuk Desa Dapurkejambon pada tahun 2014 adalah sebesar Rp 113.422.048,- yang bersumber dari bagian dana perimbangan keuangan pusat dan daerah yang diterima oleh kabupaten/kota. Apabila melihat jumlah anggaran yang diberikan kepada desa melalui Alokasi Dana Desa yaitu hingga mencapai $\mathrm{Rp}$ 113.422.048,- maka muncul pertanyaan apakah desa beserta elemen yang ada sudah mampu melaksanakan pengelolaan anggaran tersebut secara baik. Hal ini mengingat bahwa desa yang dulunya sebelum melaksanakan pembangunan hanya mendapat bantuan keuangan yang terbatas dan pengelolaannya masih sangat sentralistis oleh satuan instansi 
pemerintahan, akan tetapi setelah kebijakan alokasi dana desa diberlakukan sekarang ini, desa mendapatkan alokasi anggaran yang cukup besar dan pengelolaannya dilakukan secara mandiri. Akan tetapi, dengan kewenangan pemerintah desa dalam pengelolaan dana desa secara mandiri maka diperlukan akuntabilitas pengelolaan alokasi dana desa dalam upaya meningkatkan pembangunan dan pemberdayaan masyarakat Desa Dapurkejambon.

\section{B. Tinjauan Teoritis Pengertian Desa}

Secara etimologi kata desa berasal dari bahasa Sansekerta, deca yang berarti tanah air, tanah asal, atau tanah kelahiran. Dari perspektif geografis, desa atau village diartikan sebagai "a groups of hauses or shops in a country area, smaller than a town". Desa adalah kesatuan masyarakat hukum yang memiliki kewenangan untuk mengurus rumah tangganya sendiri berdasarkan hak asal-usul dan adat istiadat yang diakui dalam Pemerintahan Nasional dan berada di Daerah Kabupaten.

Pemerintahan desa berdasarkan Undang-Undang Nomor 6 Tahun 2014 Pasal 1 tentang desa menyebutkan bahwa Desa adalah desa dan desa adat atau yang disebut dengan nama lain, selanjutnya disebut Desa, adalah kesatuan masyarakat hukum yang memiliki batas wilayah yang berwenang untuk mengatur dan mengurus urusan pemerintahan, kepentingan masyarakat setempat berdasarkan prakarsa masyarakat, hak asal usul, dan/ atau hak tradisional yang diakui dan dihormati dalam sistem pemerintahan Negara Kesatuan Republik Indonesia.

UU Nomor 32 Tahun 2004 Desa adalah kesatuan masyarakat hukum yang memiliki batas-batas wilayah yang berwenang untuk mengatur dan mengurus kepentingan masyarakat setempat, berdasarkan asal-usul dan adat-istiadat setempat yang diakui dan dihormati dalam sistem pemerintahan Negara Kesatuan Republik Indonesia.

Selanjutnya dalam Undang-Undang Nomor 6 Tahun 2014 tentang Desa bahwa Pemerintahan Desa adalah penyelenggaraan urusan pemerintahan dan kepentingan masyarakat setempat dalam sistem pemerintahan Negara Kesatuan Republik Indonesia. 
Desa memiliki wewenang sesuai yang tertuang dalam Undang-Undang Nomor 6 Tahun 2014 tentang Desa yakni :

a. kewenangan berdasarkan hak asal usul;

b. kewenangan lokal berskala Desa;

c. kewenangan yang ditugaskan oleh Pemerintah, Pemerintah Daerah Provinsi, atau Pemerintah Daerah Kabupaten/Kota; dan kewenangan lain yang ditugaskan oleh Pemerintah, Pemerintah Daerah Provinsi, atau Pemerintah Daerah Kabupaten/Kota sesuai dengan ketentuan peraturan perundang-undangan.

Berdasarkan Undang-Undang Nomor 6 Tahun 2014 Pasal 24 bahwa Penyelenggaraan Pemerintahan Desa berdasarkan asas :

a. kepastian hukum;

b. tertib penyelenggaraan pemerintahan;

c. tertib kepentingan umum;

d. keterbukaan;

e. proporsionalitas;

f. profesionalitas;

g. akuntabilitas;

h. efektivitas dan efisiensi;

i. kearifan lokal;

j. keberagaman; dan

k. partisipatif.

\section{Alokasi Dana Desa (ADD)}

Alokasi Dana Desa atau ADD adalah bagian keuangan Desa yang diperoleh dari Bagi Hasil Pajak Daerah dan Bagian dari Dana Perimbangan Keuangan Pusat dan Daerah yang diterima oleh kabupaten. Menurut Peraturan Menteri Dalam Negeri Nomor 113 Tahun 2014 tentang Pedoman Pengelolaan Keuangan Desa, Alokasi Dana Desa, selanjutnya disingkat ADD, adalah dana perimbangan yang diterima kabupaten/kota dalam Anggaran Pendapatan dan Belanja Daerah kabupaten/kota setelah dikurangi Dana Alokasi Khusus.

Berdasarkan PP Nomor 60 Tahun 2014 Dana Desa yang bersumber pada APBN bahwa Dana Desa adalah dana yang bersumber dari Anggaran Pendapatan dan Belanja Negara yang diperuntukkan bagi Desa yang ditransfer melalui Anggaran 
Pendapatan dan Belanja Daerah kabupaten/kota dan digunakan untuk membiayai penyelenggaraan pemerintahan, pelaksanaan pembangunan, pembinaan kemasyarakatan, dan pemberdayaan masyarakat.

Berdasarkan Peraturan Undang-Undang Nomor 6 Tahun 2014 tentang Pengelolaan Keuangan Desa bahwa :

1. Keuangan desa dikelola berdasarkan asas-asas transparan, akuntabel, partisipatif serta dilakukan dengan tertib dan disiplin anggaran.

2. Pengelolaan keuangan desa dikelola dalam masa 1 (satu) tahun anggaran yakni mulai tanggal 1 Januari sampai dengan tanggal 31 Desember.

3. Kepala Desa adalah pemegang kekuasaan pengelolaan keuangan desa dan mewakili Pemerintah Desa dalam kepemilikan kekayaan milik desa yang dipisahkan. Kepala Desa sebagai pemegang kekuasaan pengelolaan keuangan desa mempunyai kewenangan:
a. menetapkan kebijakan tentang pelaksanaan APBDesa;
b. menetapkan PTPKD;
c. menetapkan petugas yang melakukan pemungutan penerimaan desa;
d. menyetujui pengeluaran atas kegiatan yang ditetapkan dalam APBDesa; dan
e. melakukan tindakan yang mengakibatkan pengeluaran atas beban APBDesa
f. Kepala Desa dalam melaksanakan pengelolaan keuangan desa, dibantu oleh PTPKD.

4. PTPKD berasal dari unsure Perangkat Desa,terdiri dari:
a. Sekretaris Desa;
b. Kepala Seksi; dan
c. Bendahara.

5. Sekretaris Desa bertindak selaku koordinator pelaksana teknis pengelolaan keuangan desa. Sekretaris Desa selaku koordinator pelaksana teknis pengelolaan keuangan desa tugas :
a. menyusun dan melaksanakan Kebijakan Pengelolaan APBDesa;
b. menyusun Rancangan Peraturan Desa tentang 
APBDesa, perubahan APBDesa dan pertanggung jawaban pelaksanaan APBDesa;

c. melakukan pengendalian terhadap pelaksanaan kegiatan yang telah ditetapkan dalam APBDesa;

d. menyusun pelaporan dan pertanggungjawaban pelaksanaan APBDesa; dan

e. melakukan verifikasi terhadap bukti-bukti penerimaan dan pengeluaran APBDesa.

6. Kepala Seksi bertindak sebagai pelaksana kegiatan sesuai dengan bidangnya. Kepala Seksi mempunyai tugas :

a. menyusun rencana pelaksanaan kegiatan yang menjadi tanggung jawabnya;

b. melaksanakan kegiatan dan/atau bersama Lembaga Kemasyarakatan Desa yang telah ditetapkan di dalam APBDesa;

c. melakukan tindakan pengeluaran yang menyebabkan atas beban anggaran belanja kegiatan; mengendalikan pelaksanaan kegiatan; melaporkan perkembangan pelaksanaan kegiatan kepada Kepala Desa; dan

d. menyiapkan dokumen anggaran atas beban pengeluaran pelaksanaan kegiatan.

7. Bendahara oleh staf pada Urusan Keuangan. Bendahara mempunyai tugas :

a. menerima, menyimpan, menyetorkan / membayar, menatausahakan, dan mempertanggungjawabkan penerimaan pendapatan desa dan pengeluaran pendapatan desa dalam rangka pelaksanaan APBDesa.

Selanjutnya Peraturan Undang-Undang Nomor 6 Tahun 2014 Pasal 8 tentang APBDesa,terdiri atas :

1. Pendapatan Desa;

2. Belanja Desa; dan

3. Pembiayaan Desa.

Pendapatan Desa terdiri atas kelompok :

a. Pendapatan Asli Desa (PADesa);

b. Transfer; dan

c. Pendapatan Lain-Lain. 
Kelompok PADesa terdiri atas jenis :

a. Hasil usaha;

b. Hasil aset;

c. Swadaya, partisipasi dan Gotong royong; dan

d. Lain-lain pendapatan asli desa.

Hasil usaha desa antara lain :

a. Hasil Bumdes, tanah kas desa.

b. Hasil aset antara lain tambatan perahu, pasar desa, tempat pemandian umum, jaringan irigasi.

c. Swadaya, partisipasi dan gotong royong adalah membangun dengan kekuatan sendiri yang melibatkan peran serta masyarakat berupa tenaga, barang yang dinilai dengan uang.

d. Lain-lain pendapatan asli desa di antara lain hasil pungutan desa.

Kelompok transfer terdiri atas jenis :

a. Dana Desa;

b. Bagian dari Hasil Pajak Daerah Kabupaten/ Kota dan Retribusi Daerah;

c. Alokasi Dana Desa (ADD);

d. Bantuan Keuangan dari APBD Provinsi; dan

e. Bantuan Keuangan APBD Kabupaten/Kota.

f. Bantuan Keuangan dari APBD Provinsi dan Kabupaten/Kota dapat bersifat umum dan khusus.

Bantuan Keuangan bersifat khusus dikelola dalam APBDesa tetapi tidak diterapkan dalam ketentuan penggunaan paling sedikit $70 \%$ (tujuh puluh perseratus) dan paling banyak $30 \%$ (tiga puluh perseratus).

Kelompok pendapatan lain-lain, terdiri atas jenis :

a. Hibah dan Sumbangan dari pihak ketiga yang tidak mengikat; dan Lain-lain pendapatan Desa yang sah.

b. Hibah dan sumbangan dari pihak ketiga yang tidak mengikat adalah pemberian berupa uang dari pihak ke tiga.

c. Lain-lain pendapatan Desa yang sah antara lain pendapatan sebagai hasil kerjasama dengan pihak ketiga dan bantuan perusahaan yang 
berlokasi di desa.

Belanja desa meliputi semua pengeluaran dari rekening desa yang merupakan kewajiban desa dalam 1 (satu) tahun anggaran yang tidak akan diperoleh pembayarannya kembali oleh desa. Klasifikasi Belanja Desa terdiri atas kelompok:
a. Penyelenggaraan Pemerintahan Desa;
b. Pelaksanaan Pembangunan Desa;
c. Pembinaan Kemasyarakatan Desa;
d. Pemberdayaan Masyarakat Desa; dan
e. Belanja Tak Terduga.

Kelompok belanja dibagi dalam kegiatan sesuai dengan kebutuhan Desa yang telah dituangkan dalam RKPDesa. Kegiatan dimaksud terdiri atas jenis belanja :
a. Pegawai;
b. Barang dan Jasa; dan
c. Modal.

Jenis belanja pegawai dianggarkan untuk pengeluaran penghasilan tetap dan tunjangan bagi Kepala Desa dan Perangkat Desa serta tunjangan BPD.

Belanja barang/jasa sebagaimana dimaksud pada ayat (1) antara lain :
a. alat tulis kantor;
b. benda pos;
c. bahan/material;
d. pemeliharaan;
e. cetak/penggandaan;
f. sewa kantor desa;
g. sewa perlengkapan dan peralatan kantor;
h. makanan dan minuman rapat;
i. pakaian dinas dan atributnya;
j. perjalanan dinas;
k. upah kerja;
1. honorarium narasumber/ahli;
m. operasional Pemerintah Desa;
n. operasional BPD;
o. insentif Rukun Tetangga / Rukun Warga; dan
p. pemberian barang pada masyarakat/kelompok masyarakat.


Akuntabilitas Pengelolaan Alokasi Dana Desa dalam Upaya ...

Insentif Rukun Tetangga / Rukun Warga adalah bantuan uang untuk operasional lembaga RT/RW dalam rangka membantu pelaksanaan tugas pelayanan pemerintahan, perencanaan pembangunan, ketentraman dan ketertiban, serta pemberdayaan masyarakat desa.

Pembiayaan Desa sebagaimana dimaksud pada ayat (1) terdiri atas kelompok :
a. Penerimaan Pembiayaan; dan
b. Pengeluaran Pembiayaan.
c. Penerimaan Pembiayaan, mencakup :
i. Sisa lebih perhitungan anggaran (SiLPA) tahun sebelumnya;
ii. Pencairan Dana Cadangan; dan
iii. Hasil penjualan kekayaan desa yang dipisahkan.

\section{Alokasi Dana Desa (ADD) dan Tujuan Pengelolaannya}

Pengelolaan keuangan Alokasi Dana Desa merupakan bagian penting yang tidak dipisahkan dari pengelolaan keuangan desa dalam APBDes. Seluruh kegiatan yang didanai oleh Alokasi Dana Desa direncanakan, dilaksanakan dan dievaluasi secara terbuka dengan melibatkan seluruh unsur masyarakat desa. Seluruh kegiatan harus dapat dipertanggungjawabkan secara administratif, teknis dan hokum (Aprisiami Putriyanti : 2012).

Berdasarkan PP Nomor 60 Tahun 2014 tentang Desa yang bersumber pada APBN bahwa besaran Dana Desa setiap kabupaten/kota bupati/walikota menetapkan besaran Dana Desa untuk setiap Desa di wilayahnya. Besaran Dana Desa setiap Desa berdasarkan jumlah penduduk Desa, luas wilayah Desa, angka kemiskinan Desa, dan tingkat kesulitan geografis. Jumlah penduduk Desa, luas wilayah Desa, dan angka kemiskinan Desa dihitung dengan bobot:

a. $30 \%$ (tiga puluh per seratus) untuk jumlah penduduk Desa;

b. $\quad 20 \%$ (dua puluh per seratus) untuk luas wilayah Desa;

c. $50 \%$ (lima puluh per seratus) untuk angka kemiskinan Desa.

\section{Akuntabilitas}

Akuntabilitas dalam penyelenggaraan pemerintahan 
daerah diartikan sebagai kewajiban Pemerintah Daerah untuk mempertanggungjawabkan pengelolaan dan pelaksanaan pemerintahan di daerah dalam rangka otonomi daerah untuk mencapai tujuan yang telah ditetapkan melalui media pertanggungjawaban yang terukur baik dari segi kualitasnya maupun kuantitasnya. Pemerintah daerah sebagai pelaku pemerintahan harus bertanggungjawab terhadap apa yang telah dilakukannya terhadap masyarakat dalam rangka menjalankan tugas, wewenang, dan kewajiban Pemerintah Daerah (Sabarno:2007).

Menurut Nordiawan (2006) mengatakan "Akuntabilitas adalah mempertanggungjawabkan pengelolaan sumber daya serta pelaksanaan kebijakan yang dipercayakan kepada entitas pelaporan dalam mencapai tujuan yang telah ditetapkan secara periodik".

Untuk menilaikinerja pemerintah dalam penyelenggaraan pemerintahan harus dengan parameter dan tolak ukur yang pasti. Hal ini dimaksudkan agar kesinambungan pembangunan dan pelayanan publik dapat dikontrol dengan kriteria yang terukur. Terdapat tiga aspek untuk menilai akuntabilitas penyelenggaraan pemerintahan, ketiga aspek tersebut adalah :

1. Parameter kerja,

2. Tolak ukur yang obkektif,

3. Tata cara yang terukur,

Dari ketiga aspek tersebut yang berkaitan dengan cara mengukurnya yaitu berkenaan dengan intensitas kompetensi pokok yang harus diperankan/dilakukan/dilaksanakan oleh masing-masing pegawai berdasarkan aspek kepribadian, profesionalitas, dan hubungan sosial, sesuai dengan posisinya dalam struktur organisasi pemerintahan. Dan kemampuan aparatur pemerintah melaksanakan tugas pokok dan fungsi dalam pelaksanaan jabatannya yang menjadi tanggungjawab. Parameter kinerja pemerintah harus dijadikan acuan untuk menilai apakah suatu program yang direncanakan berhasil atau tidak dan upaya untuk mengevaluasi kenerja pemerintahan yang telah dilaksanakan pada periode tersebut. Selanjutnya tolak ukur yang objektif merupakan syarat penting dalam menilai keberhasilan suatu program pemerintah. Hal ini terkait erat dengan penilaian suatu pertanggungjawaban. Oleh karena 
itu tolak ukur keberhasilan pemerintahan harus objektif dan jelas. Selain kedua aspek tersebut, masih diperlukan juga tata cara terukur untuk menilai kinerja pemerintah. Misalnya dalam penilaian laporan pertanggungjawaban Kepala Daerah, harus dilakukan dengan metode yang sistematis dan terukur (Sabarno, 2007).

Berdasarkan Undang-Undang Nomor 6 Tahun 2014 Pasal 38 tentang pertanggungjawaban bahwa :

1. Kepala Desa menyampaikan laporan pertanggungjawaban realisasi pelaksanaan APBDesa kepada Bupati/Walikota setiap akhir tahun anggaran.

2. Laporan pertanggungjawaban realisasi pelaksanaan APBDesa terdiri dari pendapatan, belanja, dan pembiayaan.

3. Laporan pertanggungjawaban realisasi pelaksanaan APBDesa ditetapkan dengan Peraturan Desa.

4. Peraturan Desa tentang laporan pertanggungjawaban realisasi pelaksanaan APBDesa, dilampiri:
a. format Laporan Pertanggungjawaban Realisasi Pelaksanaan APBDesa Tahun Anggaran berkenaan;
b. format Laporan Kekayaan Milik Desa per 31 Desember Tahun Anggaran berkenaan; dan format Laporan Program Pemerintah dan Pemerintah Daerah yang masuk ke desa.

\section{Pembangunan Desa}

Pembangunan masyarakat pedesaan diartikan sebagai aktivitas yang dilakukan oleh masyarakat dimana mereka mengidentifikasikan kebutuhan dan masalahnya bersama. Pembangunan daerah perdesaan diarahkan pada :

1) Untuk pembangunan desa yang bersangkutan dengan memanfaatkan sumberdaya pembangunan yang dimiliki (SDA dan SDM),

2) Untuk meningkatkan keterkaitan pembangunan antara sektor (Perdagangan, pertanian dan industri) antara desa, antar perdesaan dan perkotaan, dan

3) Untuk memperkuat pembangunan nasional secara menyeluruh. Pembangunan di desa merupakan model pembangunan partisipatif yaitu suatu sistem pengelolaan pembangunan di desa bersama-sama secara musyawarah, mufakat, dan gotong royong yang 
merupakan cara hidup masyarakat yang telah lama berakar budaya wilayah Indonesia.

Sebagaimana disebutkan dalam pasal 5 Permendagri No 66 tahun 2007, karakteristik pembangunan partisipatif diantaranya direncanakan dengan pemberdayaan dan partisipatif. Pemberdayaan, yaitu upaya untuk mewujudkan kemampuan dan kemandirian masyarakat dalam kehidupan bermasyarakat, berbangsa dan bernegara sedangkan partisipatif, yaitu keikutsertaan dan keterlibatan masyarakat secara aktif dalam proses pembangunan. Pembangunan di desa menjadi tanggungjawab Kepala Desa. Kepala Desa mempunyai tugas menyelenggarakan urusan pemerintahan, pembangunan, dan kemasyarakatan. Kegiatan pembangunan direncanakan dalam forum Musrenbangdes, hasil musyawarah tersebut di ditetapkan dalam RKPD (Rencana Kerja Pembangunan Desa) selanjutnya ditetapkan dalam APBDesa. Dalam pelaksanaan pembangunan Kepala Desa dibantu oleh perangkat desa dan dapat dibantu oleh lembaga kemasyarakatan di desa.

Berdasarkan PERMENDAGRI No.114 Tahun 2014 tentang pedoman pembangunan desa : Pembangunan Desa dilaksanakan oleh Pemerintah Desa dengan melibatkan seluruh masyarakat Desa dengan semangat gotong royong.

Berdasarkan Permendagri No. 114 Tahu 2014 tentang pedoman pembangunan desa bahwa Pemerintah, pemerintah daerah provinsi, pemerintah daerah kabupaten/kota, dan Pemerintah Desa melakukan upaya pemberdayaan masyarakat Desa. Pemberdayaan masyarakat, dilakukan melalui pengawasan dan pemantauan penyelenggaraan Pemerintahan Desa dan pembangunan Desa yang dilakukan secara partisipatif oleh masyarakat Desa. Masyarakat Desa berhak melakukan pemantauan terhadap pelaksanaan Pembangunan Desa.

Berdasarkan Permendesa No 1 tahun 2015 tentang Kewenangan lokal berskala Desa bidang pemberdayaan masyarakat sebagaimana dimaksud dalam Pasal 7 huruf $d$ antara lain :

a. pengembangan seni budaya lokal;

b. pengorganisasian melalui pembentukan dan fasilitasi lembaga kemasyarakatandan lembaga adat;

c. fasilitasi kelompok-kelompok masyarakat melalui : 
Akuntabilitas Pengelolaan Alokasi Dana Desa dalam Upaya ...

i. kelompok tani;

ii. kelompok nelayan

iii. kelompok seni budaya; dan

iv. kelompok masyarakat lain di Desa

\section{Pemberdayaan Masyarakat}

Berdasarkan Permendesa nomor 5 Tahun 2015 tentang penetapan prioritas penggunaan dana desa bahwa Pemberdayaan Masyarakat Desa adalah upaya mengembangkan kemandirian dan kesejahteraan masyarakat dengan meningkatkan pengetahuan, sikap, keterampilan, perilaku, kemampuan, kesadaran, serta memanfaatkan sumber daya melalui penetapan kebijakan, program, kegiatan, dan pendampingan yang sesuai dengan esensi masalah dan prioritas kebutuhan masyarakat Desa.

Pemberdayaan merujuk pada serangkaian tindakan yang dilakukan secara sistematis dan mencerminkan pertahapan kegiatan atau upaya mengubah masyarakat yang kurang atau belum berdaya, berkekuatan, dan berkemampuan menuju keberdayaan. Makna "memperoleh" daya, kekuatan atau kemampuan merujuk pada sumber inisiatif dalam rangka mendapatkan atau meningkatkan daya, kekuatan, atau kemampuansehinggamemilikikeberdayaan.Kata"memperoleh" mengindikasikan bahwa yang menjadi sumber inisiatif untuk berdaya berasal dari masyarakat itu sendiri. Oleh karena itu, masyarakat harus menyadari akan perlunya memperoleh daya tahu kemampuan. Makna kata "pemberian" menunjukkan bahwa sumber inisiatif bukan dari masyarakat. Inisiatif untuk mengalihkan daya, kemampuan atau kekuatan adalah pihakpihak lain yang memiliki kekuatan dan kemammpuan, misalnya pemerintah atau agen-agen pembanguan lainnya.

\section{Metode Penelitian}

Penelitian survey guna memperoleh data primer mengenai kebijakan Alokasi Dana Desa di Desa Dapurkejambon. Dengan berdasarkan data yang ada, penulis berupaya mendiskripsikan/menggambarkan secara sistematis, factual dan akurat mengenai fakta-fakta, sifat-sifat serta hubungan antar fenomena yang ada. 
Desa Dapurkejambon sebagai wilayah populasi yang mempunyai kualitas dan karakteristik tertentu yang dimiliki. Populasi yang akan diteliti adalah seluruh perangkat desa/ pemerintahan desa, lembaga masyarakat, dan tokoh masyarakat.

Metode yang digunakan untuk menganalisis data dalam penelitian ini adalah metode deskriptif-kualitatif yaitu teknik yang menggambarkan dan menginterpretasikan arti data-data yang telah terkumpul dengan memberikan perhatian sebanyak mungkin aspek yang diteliti pada saat itu, sehingga memperoleh gambaran secara umum dan menyeluruh tentang keadaan yang sebenarnya.

Teknik pengumpulan data merupakan langkah yang paling utama dalam penelitian, karena tujuan dari penelitian adalah mendapatkan data. Tanpa mengetahui teknik pengumpulan data, maka peneliti tidak akan mendapatkan data yang memenuhi standar data yang ditetapkan.

Teknik pemgumpulan data dapat dilakukan dengan observasi (pengamatan), interview (wawancara), kuesioner (angket), dokumentasi, dan gabungan keempatnya (Sugiyono : 2014).

Dalam penelitian kualitatif ini menggunakan 3 macam pengecekan keabsahan data :

1. Kepercayaan

Kredibilitas data dimaksudkan untuk membuktikan data yang berhasil dikumpulkan sesuai dengan keadaan yang sebenarnya. Untuk mencapai kredibilitas data peneliti menggunakan beberapa teknik

a. Trianggulasi

1. Membandingkan data hasil pengamatan dengan wawancara.

2. Membandingkan data dokumentasi dengan wawancara.

3. Membandingkan hasil temuan dengan teori.

b. Perpanjang keikutsertaan

Teknik ini menambah waktu pengamatan di Desa Dapurkejambon.

c. Pemeriksanaan teman sejawat melalui diskusi. Teknik ini dilakukan dengan cara mengespose 
hasil sementara dalam bentuk diskusi dengan pembimbing dan teman sejawat.

2. Kebergantungan

Kriteria ini digunakan untuk menjaga kehati-hatian akan dependability yaitu dosen pembimbing.

3. Kepastian

Kriteria ini digunakan untuk menilai hasil penelitian yang dilakukan dengan cara mengecek data dan informasi serta interpretasi hasil penelitian yang didukung oleh materi yang ada pada pelacakan audit.

\section{Analisis dan Pembahasan}

\section{Akuntabilitas Alokasi Dana Desa}

Merujuk dari Peraturan Daerah Kabupaten Jombang Nomor 12 Tahun 2013 tentang Anggaran Pendapatan dan Belanja Daerah yang merujuk pada Peraturan Desa Dapurkejambon Nomor 1 Tahun 2014 tentang Anggaran Pendapatan dan Belanja Desa Tahun 2014 mengenai pencairan alokasi dana desa bahwa dalam berita acara yang berisi persetujuan bersama kepala desa Dapurkejambon dan BPD Dapurkejambon tentang rancangan peraturan Desa Dapurkejambon tentang anggaran pendapatan dan belanja Desa Dapurkejambon tahun anggaran 2014 yang telah membahas dan menyetujui Rancangan Anggaran Pendapatan dan Belanja Desa tahun anggaran 2013 yang telah dievaluasi oleh Pemerintah Kabupaten Jombang yakni salah satu dari syarat pencairan ADD tahun 2014.

Alokasi Dana Desa adalah bagian dari APBDesa. Anggaran Pendapatan dan Belanja Desa, yang selanjutnya disingkat APB Desa adalah rencana keuangan tahunan Pemerintahan Desa.

Daftar Usulan Rencana Kegiatan (DURK)/Rencana Kerja Anggaran (RKA) sebagai persyaratan pengajuan pencairan alokasi dana desa tahun anggaran sudah terlaksana dengan baik sesuai peraturan yang berlaku, hal itu bisa dilihat bahwa tahun anggaran 2014 dana ADD turun tepat sesuai yang direncanakan sesuai kegiatan.

ADD yang merupakan salah satu sumber utama pendapatan desa juga harus dipertanggungjawabkan secara transparan dan akuntabel kepada masyarakat maupun 
kepada pemerintah tingkat atasnya sebagai institusi pemberi kewenangan. Dana Desa digunakan untuk membiayai penyelenggaraan pemerintahan, pembangunan, pemberdayaan masyarakat, dan kemasyarakatan.

Penggunaan Dana Desa mengacu pada DURK/RKA yang masing-masing lembaga pemberdayaan masyarakat sudah menerima sesuai kebutuhan program kerja. Diantaranya Biaya Operasional Pemerintah Desa, meliputi :

1. Biaya Operasional BPD, yang besarnya ditentukan berdasarkan PADS masing-masing desa sebesar Rp 8.506.700, digunakan untuk:
a. Pengadaan ATK
b. Biaya Rapat
c. Perjalanan Dinas

2. Biaya Operasional LPMD, maksimal Rp 2.381.900,- per tahun,digunakan untuk:
a. Pengadaan ATK
b. Biaya Rapat
c. Perjalanan Dinas.

3. Menunjang kegiatan PKK Desa sebesar Rp 3.969.700,digunakan untuk kegiatan :
a. Sekretariat
b. Belanja langsung
c. Biaya ATK
d. Biaya perjalanan dinas

4. Biaya Operasional Karang Taruna sebesar Rp 1.984.900,digunakan untuk:
a. Pengadaan ATK
b. Biaya rapat
c. Perjalanan dinas

Akuntabilitas ADD Desa Dapurkejambon sudah direncanakan sesuai dengan PTO/Perbup dan dibahas dalam rapat BPD dengan Pemerintah Desa. Dan pelaksanaan program ADD sudah sesuai dengan dengan RKA/DURK dan dipertanggungjawabkan oleh masing-masing lembaga desa/ masyarakat.

Sehingga Akuntabilitas Alokasi Dana Desa Dapurkejmabon dapat mempertanggungjawabkan kegiatannya dalam LPJ (laporan pertanggung jawaban) yang berisi berita 
acara pencairan ADD, laporan realisasi APBDesa, dan bebeapa bukti kwitansi yang nantinya dapat dilihat oleh seluruh lapisan masyarakat, apakah selama kegiatan di Dapurkajambon sudah sesuai dengan peraturan yang ada dan dana yang dipergunakan apakah sudah dipergunakan dengan sebaik-baiknya dan pertanggungjawaban.

\section{Pembangunan Desa}

Berdasarkan PERMENDAGRI No.114 Tahun 2014 tentang pedoman pembangunan desa : Pembangunan Desa dilaksanakan oleh Pemerintah Desa dengan melibatkan seluruh masyarakat Desa dengan semangat gotong royong.

Pembangunan merupakan suatu yang harus dilaksanakan agar tercipta kesejahteraan didalam masyarakat itu sendiri, baik pembangunan fisik maupun non fisik, masyarakat Desa Dapurkejambon sangat berharap penggunaan Alokasi Dana Desa ini mempunyai dampak yang benar-benar berarti dan memiliki dampak positif untuk kesejahteraan masyarakat.

DURK (Daftar Usulan Rencana Kegiatan) atau RKA yang telah diverifikasi oleh tim pembina, selanjutnya ditandatangani oleh Kepala Desa selaku penanggung jawab kegiatan. DURK yang telah ditandatangani tersebut disampaikan kepada camat untuk mendapatkan persetujuan dan selanjutnya dikembalikan kepada kepala desa. Setelah semuanya rampung maka ditetapkan Peraturan Desa tentang APBDesa yang didalamnya termuat dokumen Rencana Kerja dan Anggaran (RKA) kegiatan yang dibiayai oleh program Alokasi Dana Desa.

Dari Rencana Kerja dan Anggaran (RKA) Dapurkejambon Tahun 2014 bahwa pemanfaatan alokasi dana desa pada program pembangunan fisik direalisasikan melalui pembangunan saluran batu kali, terbukti dengan adanya berita acara yang menjelaskan bahwa pihak pertama yaitu pemerintah desa sudah menyerahkan dana ADD tahun anggaran sebesar Rp. 63.516.000,00.

Dari semua dana ADD yang digunakan dalam pembangunan fisik, pemerintah desa sudah membelanjakan semua yang diperlukan untuk pengerjaan pembangunan, itu bisa dilihat dalam rincian anggaran belanja langsung dan tidak langsung juga bisa dilihat di dalam buku kas pembantu. 
Dapat diketahui bahwa pemberian ADD di Desa Dapurkejambon banyak tujuan diantaranya, adalah :

1. Meningkatkan penyelenggaraan pemeritahan desa dalam melaksanakan pelayanan pemerintahan, pembangunan dan kemasyarakat sesuai dengan kewenangannya.

2. Meningkatkan kemampuan lembaga kemasyarakatan di desa dalam perencanaan, pelaksanaan dan pengendalian pembangunan serta partisipatif sesuai dengan potensi yang dimiliki.

3. Meningkatkan pemerataan pendapatan, kesempatan kerja dan kesempatan berusaha bagi masyarakat desa dalam rangka pengembangan social ekonomi masyarakat.

4. Mendorong peningkatan partisipasi swadaya gotong royong masyarakat.

Tabel Lembaga Pemberdayaan Masyarakat Desa ADD Desa Dapurkejambon 2014

\begin{tabular}{|llll|}
\hline Tanggal & Jenis Kegiatan & Besarnya (Rp) & Manfaat \\
28-09-2014 & Pembangunan & 63.516.000,00 & Sebagai wadah \\
& fisik saluran batu & air hujan supaya \\
& kali & tidak banjir \\
& & karena sebelum \\
& & pembangunan \\
& & setiap musim \\
& hujan selalu banjir \\
\hline
\end{tabular}

Sumber : laporan perencanaan ADD 2014

Tabel Tingkat kehadiran forum musyawarah desa

\begin{tabular}{|llll|}
\hline No & Unsur yang Diundang & $\begin{array}{l}\text { Jumlah } \\
\text { Undangan }\end{array}$ & $\begin{array}{l}\text { Ju m mah } \\
\text { Hadir }\end{array}$ \\
1 & Kapala Desa & 1 & 1 \\
2 & Badan Permusyawaratan Desa & 6 & 6 \\
3 & Unsur LPMD & 6 & 2 \\
4 & Unsur Kelembagaan Desa & 4 & 3 \\
5 & Tokoh Masyarakat & 18 & 18 \\
6 & Kepala Dusun & 3 & 2 \\
& Jumlah & 38 & 32 \\
\hline
\end{tabular}

Sumber : laporan hasil musrenbangdes Desa Dapurkejmbon 
Dari data tersebut tingkat partisipasi (kehadiran) dalam pengambilan keputusan masih relatif tinggi yaitu di atas $90 \%$. Hal ini menunjukkan bahwa kepedulian/ tingkat kesadaran masyarakat desa dalam mengambil peran aktif dalam pengelolaan pembangunan sebenarnya cukup tinggi. Walaupun ada beberapa tokoh masyarakat yang datang hanya sekedar memenuhi undangan untuk hadir dalam forum musyawarah desa. Namun demikian kehadiran tersebut dapat mendukung tugas pemerintah dalam mengenali kebutuhan masyarakat, menyusun agenda dan prioritas pelayanan, serta mengembangkan program-program pelayanan sesuai dengan kebutuhan dan aspirasi masyarakat.

Rencana pembangunan desa untuk menjamin keterkaitan dan konsisten antara perencanaan, penganggaran, pelaksanaan, dan pengawasan. Salah satu tujuan rencana pembangunan desa adalah mewujudkan pembangunan desa sesuai dengan kebutuhan masyarakat dan keadaan setempat.

RKPD bertujuan untuk menyiapkan DURK-PDesa yang bersifat baru, rehab maupun lanjutan kegiatan pembangunan untuk dilaporkan pada bupati/walikota melalui camat sebagai bahan dasar RKP kabupaten dan menyiapkan DURK-PDesa tahunan untuk dianggarkan dalam APBDesa.

DURK (Daftar Usulan Rencana Kegiatan) atau RKA yang telah diverifikasi oleh tim pembina, selanjutnya ditandatangani oleh Kepala Desa selaku penanggung jawab kegiatan. DURK yang telah ditandatangani tersebut disampaikan kepada camat untuk mendapatkan persetujuan dan selanjutnya dikembalikan kepada kepala desa. Setelah semuanya rampung maka ditetapkan Peraturan Desa tentang APBDesa yang didalamnya termuat dokumen Rencana Kerja dan Anggaran (RKA) kegiatan yang dibiayai oleh program Alokasi Dana Desa.

Dari Rencana Kerja dan Anggaran (RKA) Dapurkejambon Tahun 2014 bahwa pemanfaatan alokasi dana desa pada program pembangunan fisik direalisasikan melalui pembangunan saluran batu kali, terbukti dengan adanya berita acara yang menjelaskan bahwa pihak pertama yaitu pemerintah desa sudah menyerahkan dana ADD tahun anggaran sebesar Rp. 63.516.000,00.

Dari semua dana ADD yang digunakan dalam 
pembangunan fisik, pemerintah desa sudah membelanjakan semua yang diperlukan untuk pengerjaan pembangunan, itu bisa dilihat dalam rincian anggaran belanja langsung dan tidak langsung juga bisa dilihat di dalam buku kas pembantu.

Semua laporan pertanggungjawan dari pembangunan fisik sudah dilaksanakan dengan baik sesuai dengan peraturan yang ada, terbukti denagn adanya berita acara dalam penyerahan dana ADD pembangunan fisik, rincian belanja bangunan, dan juga buku kas pembantu.

\section{Pemberdayaan Masyarakat}

Lembaga Pemberdayaan Masyarakat Desa (LPMD) merupakan lembaga mitra pemerintah desa dan kelurahan dalam aspek perencanaan, pelaksanaan, dan pengendalian pembangunan yang bertumpu pada masyarakat.

Menindaklanjuti berita acara yang sudah dilampirkan bahwa dana Lembaga Pemberdayaan sudah tersalurkan dengan baik dan sudah menuangkan bidang atau programnya masing-masing dalam Rencana Kerja dan Anggaran (RKA) Desa Dapurkejambon Tahun 2014, itu bisa dilihat dari kegiatan dan secara administrasi sudah sudah tersusun dengan baik sesuai dengan peraturan yang ada dan pemerintah desa juga sudah mempertanggungjawabkan pengelolaan alokasi dana dengan membagi rata namun dalam kegiatan pemberdayaan, masyarakat Dapurkejambon kurang merespon dengan baik dan kurang berpartisipasi dalam kegiatan pemberdayaan (lihat lampiran 9).

Dari hasil penelitian sebelumnya dengan penelitian ini bahwa dari peneliti Daru Sakti Tahun 2008 dengan judul Implementasi Kebijakan Alokasi Dana Desa di Wilayah Kecamatan Geyer Kabupaten Grobogan menunjukkan bahwa Alokasi Dana Desa berjalan cukup baik, namun pencapaian tujuan pelaksanaan ADD belum optimal namun pembangunan dan kemasyarakatan telah terlaksana secara optimal. Kemampuan lembaga kemasyarakatan di desa dalam perencanaan, pelaksanaan, dan pengendalian pembangunan belum berjalan secara optimal, dengan demikian tujuan peningkatan partisipasi swadaya gotong royong masyarakat belum optimal.

Peneliti Agus Subroto Tahun 2009 dengan judul 
Akuntabilitas Pengelolaan Dana Desa di Desa Wilayah Kecamatan Tlogomulyo Kabupaten Temanggung menunjukkan bahwa perencanan dan pelaksanaan kegiatan ADD sudah akuntabel dan transparan. Dari sisi fisik sudah menujukkan akuntabel dan transparan namun dari administrasi masih diperlukan adanya pembinaan lebih lanjut karena belum sepenuhnya sesuai ketentuan. Kendala utamanya adalah soal SDM sehingga memerlukan pendampingan dari aparat pemerintah daerah secara berkelanjutan.

Peneliti Aprisiami Putriyanti Tahun 2012 dengan judul Penerapan Otonomi Desa dalam Menguatkan Akuntabilitas Pemerintah Desa dan Pemberdayaan Masyarakat di Desa Aglik Kecamatan Grabag Kabupaten Purworejo menunjukkan bahwa penerapan otonomi desa yaitu kewenangan desa, perencanaan pembangunan desa, dan keuangan desa. Pemberdayaan masyarakat desa dilakukan melalui program PNPM Mandiri Pedesaan, kelompok tani, kelompok ternak, dan pembuatan pupuk organik. Masih kurangnya tanggapnya masyarakat terhadap informasi laporan penyelengaraan desa serta kurangnya pengawasan terhadap pertanggungjawaban pemerintah desa. Tidak adanya pembukuan atas penyelengaraan program serta kurang sosialisasi kepada masyarakat atas program yang dicanagkan merupakan kendala utama yang dihadapi dalam proses pemberdayaan masyarakat desa.

Dari penelitian ini menunjukkan bahwa akuntabilitas ADD Desa Dapurkejambon cukup baik dan signifikan karena dari tahun ke tahun meningkat. Perencanaan, pelaksanaan, dan pertanggungjawaban sudah sesuai dengan DURK dan RKA. Rencana kerja pembangunan desa dengan mengacu pada RPJM Desa disusun RKP-Desa (ditetapkan dengan Peraturan Desa). Pembangunan dari fisik sudah berjalan dengan cukup baik, dari administrasi sudah sesuai ketentuan dan peraturan. Masyarakat desa turut ikut berpartisipasi dalam pembangunan desa, namum dalam pemberdayaan masyarakat Dapurkejambon dalam program pelatihan-pelatihan sangat minim minat dari masyarakat.

Kemudian dari ketiga penelitian diatas yang sesuai dengan dengan penelitian ini adalah penelitian milik Agus Subroto dan Aprisiami Putriyanti yaitu mengenai penelitian 
tentang perencanaan dan pelaksanaan Alokasi Dana Desa yang pengelolaannya diwujudkan secara akuntabel dan transparan. Kelebihan dari penelitian ini adalah pertanggungjawaban dari segi fisik maupun non fisik sudah berjalan optimal namun peneliti Agus Subroto hanya pertanggungjawaban dari segi fisik saja.

\section{E. Simpulan dan Saran}

Pertanggungjawaban ADD baik secara teknis maupun administrasi sudah berjalan dengan baik sesuai peraturan yang berlaku dengan bukti adanya pertanggungjawaban secara tranparan dan akuntabel.

Pemerintah Desa Dapurkejambon sudah mempertanggungjawabkan pengelolaan alokasi dana desa dengan baik sesuai dengan peraturan yang ada, hal itu terbukti dengan adanya Laporan Pertanggung Jawaban (LPJ) yang isinya terdapat buku kas pembantu, kwitansi, dan kegiatan-kegiatan lainnya

Laporan realisasi dan laporan pertanggungjawaban realisasi pelaksanaan APBDesa diinformasikan kepada masyarakat secara tertulis dan dengan media informasi yang mudah diakses oleh masyarakat. Rencana Kerja dan Anggaran (RKA) Dapurkejambon Tahun 2014 bahwa pemanfaatan alokasi dana desa pada program pembangunan fisik direalisasikan melalui pembangunan saluran batu kali, terbukti dengan adanya pelaksanaan pembangunannya yang sudah selesai dilaksanakan.

Perencanaan, pelaksanaan, pertanggungjawaban pembangunan dan pemberdayaan desa Dapurkejambon sudah dilakukan oleh pemerintah desa sesuai dengan peraturan yang ada, terbukti dengan adanya tahapan perencanaan kegiatan dapat dilakukan persiapan berupa penyusunan Daftar Usulan Rencana Kegiatan (DURK) dan Rencana Kerja Anggaran (RKA) yang kegiatannya dibiayai oleh Alokasi Dana Desa. Namun demikian tujuan Alokasi Dana Desa dalam meningkatkan pemberdayaan masyarakat Dapurkejambon masih dirasa kurang optimal karena masyarakat kurang merespon dengan baik.

Kegiatan Alokasi Dana Desa yang berbentuk pemberdayaan masyarakat yang dilaksanakan oleh LPMD, hal ini dapat diharapkan programnya akan memberikan kesadaran 
Akuntabilitas Pengelolaan Alokasi Dana Desa dalam Upaya ...

pada masyarakat bahwa pemberdayaan bukanlah umtuk kepentingan Pemerintah Desa namun untuk kepentingan masyarakat itu sendiri. Dan mungkin lembaga pemberdayaan masyarakat dapat mengadakan kegiatan atau program yang lebih bervariasi atau lebih banyak untuk menarik masyarakat supaya tertarik dengan pelatihan tersebut.

Dalam rangka penyelenggaraan pemerintah desa disusun perencanaan pembangunan desa sebagai kesatuan dalam system perencanaan pembangunan daerah. Dengan adanya perencanaan pembangunan desa yang terpadu dengan system perencanaan desa diharapkan semua program yang disusun dan dilaksanakan dapat tepat sasaran. 


\section{DAFTAR PUSTAKA}

Aprisiami Putriyanti., 2012., Penerapan Otonomi Desa dalam Menguatkan Akuntabilitas Pemerintahan Desa dan Pemberdayaan Masyarakat di Desa Aglik Kecematan Grabag Kabuoaten Purworejo., Yogjakrta : UNY

Mahfudz. 2009, Analisis Dampak Alokasi Dana Desa (ADD) Terhadap Pemberdayaan Masyarakat dan Kelembagaan Desa., Jurnal Organisasi dan Manajemen., Volume 5, Nomor 1

Nordiawan, Dedi, 2006, Akuntansi Sektor Publik, Jakarta : Salemba Empat

Peraturan Bupati Jombang No. 3 Tahun 2011 Tentang Pedoman Pengelolaan Alokasi Dana Desa Kabupaten Jombang

Peraturan Menteri dalam Negeri Nomor 7 Tahun 2007 Tentang Kader Pemberdayaan Desa

Peraturan Pemerintah Nomor 43 Tahun 2014 tentang Pelaksanaan UU Nimir 6 Tahun 2014 Tentang Desa

Peraturan Pemerintah Nomor 60 Tahun 2014 Tentang Dana Desa yang Bersumber pada APBN

Peraturan Menteri dalam Negeri Nomor 113 Tahun 2014 Tentang Pengelolaan Keuangan Desa

Peraturan Menteri dalam Negeri Nomor 114 Tahun 2014 Tentang Pedoman Pembangunan Desa

Peraturan Menteri Desa Nomor 1 Tahun 2015 Tentang Pedoman Kewenangan berdasrkan Hak Usul dan Kewenangan Lokal Berskala Desa

Peraturan Menteri Desa Nomor 5 Tahun 2015 Tentang Penetapan Prioritas Penggunaan Dana Desa 
Akuntabilitas Pengelolaan Alokasi Dana Desa dalam Upaya ...

Sugiyono., 2014, Metode Penelitian Bisnis., Jakarta : Airlangga

Widjaja., HAW., 2004 Otonomi Daerah Merupakan Otonomi Yang Asli, Bulat, dan Utuh., Jakarta : PT. Raja Grafindo Persada

Undang-Undang Nomor 6 Tahun 2014 Tentang Desa 